3. Dollard, John; Miller, Neal E.; Doob, Leonard W.; Mowrer, Orval H.; Sears, Robert R. Frustration and Aggression. New Haven, CT, US: Yale University Press, 1939.

4. Бандура А., Уолтерс Р. Подростковая агрессия. Изучение влияния воспитания и семейных отношений. Москва. Серия: Психология. XX век, 2000, 512 с.

5. Huesmann L.R., Moise J. Media violence; A demonstrated public threat to children// Harvard Mental Health Letter, 1996, vol. 12.

6. Хекхаузен Х. Мотивация и деятельность. М.: Смысл. 2003, 860 с.

DOI https://doi.org/10.30525/978-9934-588-80-8-1.49

\title{
ПСИХОЛОГІЧНІ ОСОБЛИВОСТІ ПРОЯВУ СИНДРОМУ ЕМОЦІЙНОГО ВИГОРАННЯ У ЮРИСТІВ
}

\author{
Шпак М. М. \\ доктор психологічних наук, доцент,
} професор кафедри психології розвитку та консультування

Тернопільський національний педагогічний університет імені Володимира Гнатюка

Ороновська О. М.

магістрантка кафедри психологї̈ розвитку та консультування (спеціальність «Психологія»)

Тернопільський національний педагогічний університет імені Володимира Гнатюка м. Тернопіль, Украӥна

Професійна діяльність юриста вимагає наявності низки професійно значущих та особистісних якостей, які б забезпечували психологічну готовність фахівця до роботи в напружених, емоціогенних умовах, стресових ситуаціях, які можуть призвести до синдрому «емоційного вигорання».

Проблема емоційного вигорання була предметом дослідження багатьох вітчизняних (В. Бойко, I. Ващенко, Н. Водоп'янова, Л. Карамушка, М. Смульсон, Н. Чепелєва, Л. Юр'єва та ін.) та зарубіжних (Дж. Грінберг, А. Ленгле, К. Маслач, Дж. Моллі, Дж Сторлі, Г. Фрейденбергер та ін.) психологів. У працях цих учених розкрито зміст, соціально-психологічні чинники та ознаки прояву емоційного вигорання особистості. Однак вивченню особливостей прояву синдрому емоційного вигорання у юристів присвячено невелику 
кількість робіт (І. Ващенко, Р. Каламаж, О. Крапівіна, О. Луніна, В. Медведєв, Н. Поварова та ін.).

Діяльність юристів спрямована на забезпечення верховенства права та встановлення істини і справедливості. Здійснюючи правосуддя, юридичні працівники повинні проявляти не лише високий рівень професійної компетентності, відповідальності, а й стресостійкості, здатності до емоційної саморегуляції, уміння ефективно розв'язувати конфліктні ситуації. Це зумовлює необхідність забезпечення психологічного супроводу професійної діяльності юристів та, водночас, потребу в наукових психологічних дослідженнях, спрямованих на попередження та ефективне подолання емоційного вигорання у юридичних працівників.

Аналіз психологічної літератури з проблеми дослідження свідчить про те, що емоційне вигорання розглядається дослідниками 3 позицій різних наукових підходів та концептуальних моделей. При цьому немає чіткого і однозначного визначення змісту цього поняття. У наукових публікаціях використовується чимало термінів-синонімів, зокрема: вигорання (Н. Водоп'янова), емоційне згорання (Т. Форманюк), психічне вигорання (Н. Водоп'янова, В. Орел, С. Харенко та ін.), професійне вигорання (Л. Карамушка, Т. Зайчикова, К. Писанко, Л. Юр'єва та ін.).

Найпоширенішим і одним з найбільш значущих у контексті нашого дослідження є професійно-орієнтований підхід, в якому провідна роль у розвитку емоційного вигорання належить передусім особливостям професійної діяльності: іiї умовам, функціям, завданням та середовищу загалом [2, с. 14]. Так, наприклад, В. Бойко розглядає «емоційне вигорання» як «вироблений особистістю механізм психологічного захисту у формі повного або часткового виключення емоцій у відповідь на вибіркові психотравмуючі дії, набутий стереотип емоційної, найчастіше професійної, поведінки» [1, с. 122]. Вчений зазначає, що емоційне вигорання - це динамічний процес, який розвивається поступово. Він починається із сильного й тривалого стресу на роботі, коли вимоги до людини (внутрішні та зовнішні) постійно перевищують наявні в неї ресурси, що призводить до порушення стану психофізіологічної рівноваги [1].

К. Маслач характеризує професійне вигорання як порушення психіки, що не виходить за межі психічної норми і $є$ реакцією суб'єкта на тривалі стреси, зумовлені виробничими взаєминами [6]. На думку дослідниці, емоційне вигорання $\epsilon$ результатом впливу комплексу стресогенних чинників, 3 якими працівник стикається в процесі професійної діяльності.

Встановлено, що емоційне вигорання позначається на ефективності виконання працівником професійних обов'язків, негативному ставленні до самої роботи, на взаєминах з колегами по роботі і членами сім'ї, 
оскільки призводить до особистісної тривожності, депресії, втоми, незадоволеності собою, виникнення конфліктів у професійному середовищі, неадекватного емоційного реагування на службові та життєві ситуації [1; 4].

На думку В. Бойка, причиною емоційного вигорання фахівця можуть бути як зовнішні чинники, що стосуються особливостей професійної діяльності, так і внутрішні, які пов'язані з індивідуальнопсихологічними особливостями самих працівників. До зовнішніх чинників дослідник відносить: 1) напружену психоемоційну діяльність; 2) дестабілізуючу організацію діяльності; 3) підвищену відповідальність за виконання покладених обов'язків; 4) несприятливу психологічну атмосферу професійної діяльності; 5) психологічно важкий контингент, з яким доводиться спілкуватися під час здійснення діяльності. Серед внутрішніх чинників емоційного вигорання В. Бойко виокремлює: 1) схильність до емоційної ригідності; 2) інтенсивне сприйняття та переживання обставин діяльності; 3) слабку мотивацію емоційної віддачі у діяльності; 4) моральні дефекти та дезорієнтацію особистості [1].

Дослідники стверджують, що в сучасних умовах розвитку суспільства різко зростає прояв емоційного вигорання саме у фахівців професій типу «людина-людина», зокрема, й у юридичних працівників.

Специфіка роботи юриста як суб'єкта професійної діяльності характеризується такими психологічними особливостями діяльності, якот: висока регламентованість, постійно діючі терміни, екстремальність, професійний ризик, психічне i фізичне перевантаження, прагнення виграти справу, а також підвищена відповідальність [4]. Крім того, професійна юридична діяльність полягає у щоденному спілкуванні 3 людьми. До того ж, емоційне вигорання в юридичній діяльності зумовлено ще й переживанням внутрішньої конфліктності. Як зазначає Р. Каламаж, це простежується в тому, що юристові потрібно поєднувати у своїй роботі протилежні вектори ставлення до людини, як-от: одночасно боротися «за», відстоюючи інтереси свого клієнта, але одночасно й «проти» інтересів протилежної сторони, що призводить до складної боротьби морально-етичних установок фахівця [3].

Доведено, що емоційне вигорання розглядається як процес, якому притаманні певні стадії розвитку. Найбільш поширеною й визнаною у психологічній науці $є$ модель емоційного вигорання, запропонована К. Маслач, яка виокремлює три структурні складові: емоційне виснаження, деперсоналізацію та редукцію професійних досягнень [5]. Емоційне виснаження $\epsilon$ першим симптомом 3 якого розпочинається процес вигорання. Воно проявляється переважно у формі надмірного переживання психотравмуючих обставин, тривоги та депресії. Деперсоналізація передбачає негативне ставлення до професійної діяльності та людей, 3 якими фахівець взаємодіє. Вона характери- 
зується байдужістю та дистанціюванням від власних проблем та інших людей. Людина поступово стає працювати як робот, як бездушний автомат. Редукція професійних досягнень пов'язана зі зниження бажання працювати, незадоволеністю собою та результатами своєї праці. Таким чином, емоційне вигорання проявляється як в когнітивній, емоційно-вольовій сферах, так і в поведінці фахівця, і характеризується психосоматичними, особистісними та професійними порушеннями.

3 метою запобігання емоційного вигорання у юристів важливе значення мають: 1) особливості професійної діяльності: сприятливе професійне середовище, емоційний клімат в колективі, підтримка колег, друзів, уміння працювати в команді, позитивна оцінка ефективності роботи фахівця, застосування моральних та матеріальних заохочень; 2) організациійні умови роботи: правильна організація праці і режиму дня, наявність умов для відпочинку і релаксації, ефективний розподіл робочого навантаження, уміння розставляти пріоритети визначити, які завдання є важливим і першочерговими, а які можна відкласти; 3) індивідуально-психологічні особливості: формування позитивної мотивації досягнень, адекватної самооцінки, уміння здійснювати емоційний самоконтроль.

Перспективи подальших наукових досліджень вбачаємо у пошуку психологічних засобів та розробці програми психопрофілактики емоційного вигорання у юристів.

\section{Література:}

1. Бойко В. В. Синдром «эмоционального выгорания» в профессиональном общении. Санкт-Петербург: Сударыня, 2001. 434 с.

2. Водопьянова Н. Е., Старченкова Е. С. Синдром выгорания. Санкт-Петербург: Питер, 2008. 336 с.

3. Каламаж Р. В. Психологія становлення професійної Я-концепції майбутніх юристів: монографія. Острог: Вид-во НаУОА. 2009. 404 с.

4. Писанко К. В. Взаємозв'язок рис особистості та детермінант прояву синдрому професійного вигорання у юристів. Проблеми загальної та педагогічної психології: зб. наук. праць Інституту психології ім. Г. С. Костюка НАПН України / За ред. С. Д. Максименка. Київ, 2010. Т. ХII, част. 5. С. 270-277.

5. Maslach C. Burnout: A multidimensional perspective // Professional burnout: Recent developments in the theory and research / Ed. W.B. Shaufeli, C. Maslach, T. Marek. Washington D.C.: Taylor \& Trancis, 1993. P. 19-37.

6. Maslach C., Leiter M. P. The truth about burnout: How organizations cause personal stress and what to do about it. San Francisco, CA: JosseyBass, 1997. $186 \mathrm{p}$. 